\title{
Слике света - традиционални и савремени фолклор у интердисциплинарном контексту
}

\author{
Лидија Стојановиќ
}

Тематскиот број посветен на македонската фолклористика, симболично насловен Слике света: Традищионални и савремени фолклор у интердисциплинарном контексту го претставуваат шест интересни трудови, кои не само што опфаќаат неколку поддисциплини на фолклористиката, (наративен фолклор, орнаментална сакрална култура, народни обичаи, празнувања, народна култура), туку ја рефлектираат и современата состојба на истражувачката идеја на некои области од фолклористиката како научна дисциплина. Се согледуваат традиционални светови, архетипски слики, космогониски симболи, се прикажува интердисциплинарното доживување на лиминалните светови во книжевната и културна атмосфера на Македонија во 19 век; симбиозата на традиционалната, современата и футуристички отсликана парадигма на македонската народна култура, согледана преку прославата на карневалот во Вевчани, како и испитување на еден сегмент од современиот технизиран свет - оној на видео игрите. Есеизираниот поглед на македонската фолклористика во 21 век, на извесен начин ја презентира современата теориска и методолошка позиција на оваа дисциплина.

Со овој темат се означуваат големите јубилеи: 70 години од создавањето на Институтот за фолклор „Марко Цепенков“ (1950 г.), како и 100 годишнината од смртта на големиот македонски собирач Цепенков (1829-1920). Воедно, ова издание претставува уште една промоција на македонската фолклористика по онаа во Народна творчість та етнографія. Спецвипуск: Македонська фольклористика №3. Київ, 2009, и во Сучасна зарубіжна етнологія. Ганна Скрипник. (Ур.), Київ 2010.

Тематскиот број го започнуваат два труда на Оксана Микитенко и Акад. Катица Ќулавкова од областа на македонската народна култура кои го опфаќаат феноменот на карневализмот и лиминалноста. 
Оксана Микитенко во својот труд дава анализа на еден специфичен симбол на македонската народна култура - карневалот во Вевчани. Базирајќи се на сопствените теренски истражувања (13-14 јануари 2019), таа не само што дава преглед на карневалската култура како облик на изразување, туку ги дава теориските согледувања на Бахтин за културата на смеење, спроведува истражување на традиционалната култура на Македонија во споредба со соседните култури, а пред се́ врши студиозна анализа на самиот празник (историски, теренски белешки, блиски обрасци). На тој начин го открива неговото значење во рамките на целото општество. Трудот се базира на нејзини сопствени теренски набудувања за време на посетата на зимскиот карневал Василица во 2019 година во селото Вевчани кај Охрид, што се одржува секоја година на денот на Св. Василиј (13-14 јануари). Поврзан со новогодишните ритуали, празникот Василица ја покажува традицијата на ритуално маскирање во периодот на т.н. Нечисти (некрстени) денови, помеѓу Божиќ и Водици, и е позната низ целата етничка територија на Македонија со различни имиња на учесници. Традиционалната драма (П. Богатирјов, М. Китевски), што се изведува за време на Василица, е имитација на свадбен ритуал и е еден од елементите на обредното однесување со актуелизирање на семантиката на плодноста во контекст на годишната транзиција. Карневалот Вевчани, кој е член на Меѓународната асоцијација за карневали, има долга традиција на одржување. Тука забележуваме истовремено присуство на традиционални и современи елементи на културата кои го ставаат празникот во еден сосема поинаков контекст, обележан со процесите на масовната култура и потребите на потрошувачкото општество. Земајќи го предвид карневалот во Вевчани во контекст на современата глобализација, доаѓаме до заклучок за важноста на карневалот за социо-економските потреби, но и како синергија на традиционалната и модерната празнична култура со улога на одржување на идентитетот на микро и макро ниво.

Академик Катица Ќулавкова го обработува феноменот на граничноста/лиминалноста на македонската култура во 19 век, кој е карактеристичен особено за преодните периоди од развојот на културата и општеството, како на поширок, така и на одделен план. Според авторката Ќулавкова, се јавуваат неколку парадигми на лиминалност: културен триаголник, фолклоризам и карневализација како облик на дијалог помеѓу црковната и граѓанска култура спрема фолклорната. Според неа, културата на македонската Преродба е попрво систем на гранични, одошто на поларизирани културни обрасци. Македонската граѓанска култура се дистанцирала и од фолклорната, и од црковната културна практика, така што го избегнала грубиот антагонизам. Би 
можело да се зборува за еден културен триаголник, кој претставувал уводна фаза во преминот кон модерните плурални културни системи.

Втората парадигма на лиминалноста е претставена преку фолклоризмот. Во преродбеничката култура во 19 век единствено фолклоризмот ја поседува моќта да се изврши фузијата помеѓу народната маса и учените. Во 19 век, кога на Балканот се провлекуваат елементи на доцно средновековие и пост-средновековие, се јавуваат нови околности и се потиснува првичниот биполарен однос меѓу народната и црковната култура. Се воспоставуваат нови односи во културата, препознатливи по зголемениот сензибилитет за различните културни практики. Во такво цивилизациско опкружување, се јавува потреба од адаптирање, како на христијанската, така и на народната култура. Од една страна, се создава еден граничен облик на фолклорна култура. Според Гуревич, „фолклоризираното христијанство“ живеело напоредно со магијата и „анимистичката свест“. Фолклоризмот, сфатен како доминантна културна матрица на втората половина на 19 век во Македонија, врши улога на примарен фактор во националното освестување на Македонците, кое доаѓа до израз во нивните јасно искажани културни, јазични и национални политики од крајот на 19 и почетокот на 20 век (Димитар Македонски Беровски, Ѓорѓија Пулевски, Крсте Мисирков, Димитрија Чуповски). Овој тип на релации спонтано води кон третата парадигма на лиминалниот идентитет - карневализмот. Црковната и граѓанската варијанта на т.н. висока култура не се толку категорично противставени на „ниската“ народна култура. Разликите се неспорни но, исто така не е спорно дека и двете практики покажуваат интерес за фолклорот и фолклорната свест и дека се отвораат спрема некои елементи на популарната култура. Таа отвореност на црковната и на граѓанската култура спрема фолклорната создава услови за контакт меѓу нив, а со тоа и за нивна „карневализација“. Тој е израз на исконскиот човечки револт против табуата и стремежот за слобода, затоа што го претставува другото лице на слободата и ослободувањето од предрасудите, стравот и стигмите.

Во трудовите на Никос Чаусидис и Анџела Грубер интермедијално се претставени архетиписките митолошки обрасци на големата мајка и создавање на светот. Повод за истражувањето на Никос Чаусидис е еден необичен детал од прочуената фрескокомпозиција „Оплакување Христово“ од црквата во манастирот Нерези кај Скопје. Во оваа сцена покојниот Христос лежи во ромбичното поле што го формираат нозете на Богородица кои се со раширени колена, споени стапала и целосно покриени со нејзиното здолниште. Во истражувањето е вклучена 
и фигурата на Рахела, прикажана во слична поза, во сцената „Колеж на Витлеемските деца“ од Марковиот манастир кај Скопје, како и неколку претстави на Геа од композициите „Страшен суд“. Целта на статијата се состои во трагање по карактерот, потеклото и значењето на специфичната поза во која жена се прикажува со раширени бедра и колена и споени стапала, при што нејзините нозе формираат ромб. Во трудот се прави обид за откривање на значењето на овој иконографски елемент преку анализа на двете суштински компоненти на посочената поза, од една страна семиотиката на женските нозе и тоа посебно раширените, и од друга симболиката на ромбот. До неговиот карактер и потекло се доаѓа преку споредба на посочените ликовни претстави со аналогии, присутни во други култури, кои потекнуваат од разни делови на светот и разни периоди - од предисторијата до современиот фолклор. Во нив телото на жената е на разни начини комбинирано со ромб и тоа: дополнето со ромб, целосно метаморфозирано во ромб или прикажано со нозе кои со својата поза формираат ромб. Релациите пак со земјата се должат на архаичните претстави (доминантни во поголемиот дел од светот) за земјата како четиристрана плоча кои се должат на четворниот систем на ориентација и сетилна перцепција кој му е вроден на човекот како биолошки вид.

Во фокусот на истражувањето на Анџела Грубер се митовите за создавањето на светот од телото на некое прасуштество во кои разните негови телесни делови се врзуваат со настанокот на одделни космички елементи. Овој тип космогониски митови се јавува во бројни култури и тоа во разни географски подрачја на светот и разни историски периоди, проследени со одредени специфичности. Убивањето на ова суштество го реализираат разни ликови (од категоријата прв човек, културен херој итн.) кои се борат со чудовиштето, го убиваат и од деловите на неговото тело го градат светот.

Целите нанејзиното истражување сеоткривањеи иеконструкција на локалните варијанти на посочените космогониски митови во фолклорот на територијата на Македонија. Траги од овој мит се забележани во народната книжевност, ликовните престави и обредните традиции од територијата на Македонија, како и подрачјата од нејзиното непосредно опкружување. проследено со соодветни варијанти во рамките на индоевропскиот ареал и пошироко. Со помош на компаративниот метод таа ги опфаќ: дејствието, митските ликови, нивните функции, заемните односи, употребениот систем на симболи и метафори. Најзначајниот дел од истражувањето го претставуваат примерите од зборниците на Миладиновци, Верковиќ, Цепенков, Јастребов, некои од поновите записи од 20 век, како и архивските материјали од Институтот за фолклор „Марко Цепенков“. Истите мотиви се на- 
ведени и во визуелниот медиум: станува збор за сцени изведени во вид на фрескокомпозиции или икони настанати во рамките на култот на Св. Ѓорѓ кој бил мошне популарен на овој регион. Наведени се: фрескокомпозицијата во црквата Св. Ѓорѓ в во с. Старо Нагоричане, Куманово која датира од 14 век и иконата Св. Горѓи убива змеј во црквата Св. Ѓорѓи во Струга која датира од третата четвртина на 14 век. Авторката го анализира дуелот согледан преку сликите на т.н. културен херој, светец кој убива аждер/ламја, слики на панкосмичкиот змеј како парадигма на ликот на ламјата од Балканските простори итн. Логично, преовладуваат примерите во кои се чувствува interpretatio christiana.

Наредните два труда презентираат дел од современата македонска фолклористика: прашањето на теориско-методолошката позиција на фолклористиката како дисциплина на Ермис Лафазановски и интердисциплинарното истражување на Кристина Димовска, која многу умешно одговара на поставената тема.

Ермис Лафазановски дава еден интересен есеистички преглед на концептот на фолклористиката во Македонија во последните седумдесет години, неколкукратно ревидирајќ ја релацијата: традиција и современост. Инспириран од трудот на Дандес, тој ја согледува неопходноста на македонската фолклористика по проаоѓање на сопствена методолошка матрица. Како и во светски рамки, така и во македонската фолклористика, особено во доменот на народната книжевност, истражувањата се́ повеќе ги напуштаат старите филолошки матрици и преоѓаат во сфера на социолошки насочени анализи, што е условено од промените во стилот на живеење. Во заклучокот кажува дека македонската фолклористика методолошки треба да се движи во насока на критичката анализа на културата, добро познатата идеја на школата на Баузингер. Лафазановски се залага за согледување на фолклористиката како медиум за анализа на културата.

Кристина Димовска, истражувајќ еден аспект од современото секојдневие, врши анализа на неколку видео игри, повикувајќи се на Кембеловиот концепт на мономитот од студијата Херојот со илјада лица. Освен формалното дефинирање и експликација на структурата на мономитот (стадиуми и посебни фази), таа дава образлагање на примената на концептот како интермедијална алатка за анализа на преносот и на трансформацијата на мономитот врз неколку репрезентативни видео-игри: Dark Stone, Breathe of Fire III-IV, Valkyrie Profile, Valkyrie Profile 2: Silmeria, Ōkami, Persona 2, Rogue Galaxy, Warcraft III, Shadow of the Colossus и други. Селекцијата на наведениве видео-игри е извршена врз основа на нивните споделени мотиви и хронотопи во стадиумите и фазите на мономитот, но и на нивната припадност 
кон жанрот авантура/RPG (Role Play Game/gaming)/RTS (Real-Time Strategy). Посебен акцент е ставен на интермедијалниот „пренос“ на мономитот во споменатите видео-игри. Таа врши едно современо интермедијално истражување на архетипот на иницијација, согледано во новиот медиум (видео игри), при што таа дава една нејзина лична дистинкција помеѓу категоријата херој и јунак.

Во една неверојатно меланхолична година (2020), не случајно овој тематски број го претставуваат симболи на: создавање на светот, големата мајка, карневалската култура, аспекти на современата авантуристичка забавна култура (видео игри) и оптимизам изразен преку големото ура за македонската фолклористика.

Истражувања даваат не само претстава за присутноста на идеите, симболите, сликите, кои се предмет на анализите, туку исто така рефлектираат и начин на кој се истите согледани од страна на учесниците во овој број кој може да биде надограден со секаков вид на понатамошен дијалог.

Лидија Стојановиќ

Институт за фолклор „Марко Цепенков“

Универзитет „Св. Кирил и Методиј“,

Скопље, Северна Македонија

Примљено: 11. 12. 2020.

Е-пошта: lidijast@ukim.edu.mk

Прихваћено: 26. 12. 2020. 